\title{
PENGARUH KEDISIPLINAN BELAJAR TERHADAP PRESTASI BELAJAR MURID KELAS V SD NEGERI SUMANNA KEC.TAMALATE KOTA MAKASSAR
}

\author{
Wardatul Adawiyah, M. Basri, M. Hanis Nur. \\ Pendidikan Guru Sekolah Dasar, Fakultas Keguruan dan Ilmu Pendidikan, \\ Universitas Muhammadiyah Makassar \\ Iqramsyar34@gmail.com
}

\begin{abstract}
ABSTRAK
Masalah dalam penelitian ini yaitu disiplin belajar .Rumusan masalah dalam penelitian ini yaitu Apakah ada pengaruh kedisiplinan belajar terhadap prestasi belajar Murid SD Negeri Sumanna Kecamatan Tamalate Kota Makassar. Penelitian ini bertujuan untuk mengetahui Pengaruh kedisiplinan belajar terhadap prestasi belajar Murid SD Negeri Sumanna Kecamatan Tamalate Kota Makassar Pendekatan penelitian ini adalah pendekatan kuantitatif dengan jenis penelitian yaitu korelasional yang akan mengungkap pengaruh kedisiplinan belajar terhadap prestasi belajar SD Negeri Sumanna Kecamatan Tamalate Kota Makassar. Populasi adalah seluruh Murid di SD Negeri Sumanna yang berjumlah 240 murid sampel yaitu seluruh murid kelas V SD Negeri Sumanna Kecamatan Tamalate Kota Makassar dengan jumlah 50 murid SD Negeri Sumanna Kecamatan Tamalate Kota Makassar. Mengingat bahwa populasi penelitian sampel besar maka penulis menggunakan teknik purposive sampling teknik pertemuan secara langsung yang diukur adalah kedisiplinan belajar dengan prestasi belajar. Untuk Variabel kedisiplinan belajar, diukur dengan menggunakan angket yang disebarkan pada ke 50 orang murid kelas $\mathrm{V}$ yang terpilih sebagai responden penelitian. Variabel prestasi belajar didapat dari nilai rata-rata lapor murid dilihat dari hasil belajar. Data kedisiplinan belajar di peroleh nilai rata-rata yaitu 70.02 dan prestasi belajar di peroleh nilai rata-rata yaitu 81.02. Untuk data kedisiplinan belajar dan prestasi belajar diperoleh $r_{\text {hitung }}$ sebesar 0,69 dan nilai $r_{\text {tabel }}$ untuk $n=50$ yaitu 0,279 Nilai $r_{\text {hitung }}>r_{\text {tabel }}$ berarti terdapat pengaruh kedisiplinan belajar terhadap prestasi belajar siswa di SD Negeri Sumanna Kecamatan Tamalate Kota Makassar
\end{abstract}

Kata Kunci : Kedisiplinan Belajar; Prestasi Belajar 


\section{PENDAHULUAN}

Tata tertib adalah sesuatu yang sangat penting untuk diterapkan. Setiap sekolah mempunyai tata tertib masing-masing untuk mendisiplinkan semua aktivitas yang berlangsung di sekolah, termasuk didalamnya aktivitas belajar mengajar. Disiplin sangat penting artinya untuk mengefesienkan proses belajar mengajar. Karena pentingnya kedisiplinan ini, setiap sekolah menetapkan aturan dan tata tertib agar murid dapat berperilaku sesuai dengan apa yang diharapkan, tentu dalam kaitannya dengan proses belajar. Peraturan tata tertib merupakan sesuatu untuk mengatur perilaku yang diharapkan terjadi pada diri murid.

Perilaku disiplin tidak dapat terjadi begitu saja. Untuk membiasakan murid berperilaku disiplin diperlukan pengawasan dan pembiasaan yang harus terus menerus dilakukan sampai pada akhirnya murid terbiasa sendiri untuk berperilaku disiplin. Peran serta orang tua dalam mendidik anak berperilaku disiplin sangatlah penting. Pembiasan dari kecil untuk berperilaku disiplin seorang murid didapatkan dari pola asuh orang tuanya. Murid yang terbiasa disiplin dari kecil akan menjadikan perilaku disiplin itu menjadi karakternya. Murid yang mempunyai karakter disiplin atau yang terbiasa dengan perilaku disiplin akan mudah untuk mengerjakan tugastugas yang diberikan.

Disiplin belajar murid antara lain selalu mengikuti pelajaran, memperhatikan penjelasan guru, segera menyelesaikan tugas yang diberikan kepadanya, tidak meninggalkan kelas sebelum waktunya, selalu menyelesaikan tugas rumah tepat waktu, rutin belajar di rumah, menghargai waktu dan sebagainya.

Berangkat dari permasalahan di atas, kedisiplinan akan sangat mempengaruhi proses belajar mengajar di kelas. Dengan demikian akan sangat mempengaruhi prestasi belajar murid, demikian juga dapat mempengaruhi mutu tidaknya pendidikan yang ada di Indonesia.

Berdasarkan uraian di atas rumusan masalah dalam penelitian ini adalah "Apakah ada pengaruh kedisiplinan belajar terhadap prestasi belajar Murid Kelas V SD Negeri Sumanna Kec.Tamalate Kota. Makassar ?". Tujuan penelitian ini adalah mengetahui: (1) Untuk memperoleh data tentang kediplinan belajar murid kelas V di SD Negeri Sumanna kecamatan tamalate kota makassar. (2) Untuk memperoleh data tentang prestasi belajar murid kelas V di SD Negeri Sumanna kecamatan tamalate kota 
makassar. (3) Pengaruh kedisiplinan belajar terhadap prestasi belajar murid kelas V di SD Negeri Sumanna kecamatan tamalate kota makassar..

\section{Disiplin}

Kata disiplin sendiri sebenarnya berasal dari bahasa latin, yaitu disciplina dan discipulus yang berarti perintah dan peserta didik. Jadi, disiplin dapat dikatakan sebagai perintah seorang guru kepada peserta didiknya. Disiplin adalah suatu kondisi yang tercipta dan terbentuk melalui proses dari serangkaian perilaku yang menunjukkan nilai-nilai ketaatan, kepatuhan, kesetiaan, keteraturan dan atau ketertiban (Nursisto, 1986 :14). Nilai-nilai tersebut telah menjadi bagian perilaku dalam kehidupannya. Perilaku itu tercipta melalui proses binaan melalui keluarga, pendidikan dan pengalaman.

Menurut Koesoema (2011: 237), “istilah disiplin terutama mengacu pada proses pembelajaran". Disiplin senantiasa dikaitkan dengan konteks relasi antara murid dan guru serta lingkungan yang menyertainya, seperti tata peraturan, tujuan pembelajaran dan pengembangan kemampuan dari murid melalui bimbingan guru.

Zuriah (2011:83) yang menyatakan bahwa seseorang dikatakan berdisiplin apabila melakukan pekerjaan dengan tertib dan teratur sesuai dengan waktu dan tempatnya serta dikerjakan dengan penuh kesadaran,

Dari pendapat di atas dapat disimpulkan bahwa disiplin adalah suatu sikap dan kondisi seseorang atau sekelompok orang yang tercipta dan terbentuk melalui proses bimbingan yang bertujuan menanamkan pola perilaku yang baik, menaati normanorma, kebiasaan- kebiasaan, dan ketertiban yang telah ditetapkan.

\section{Prestasi Belajar}

Menurut Slameto (2003 :3) belajar adalah "suatu proses usaha yang dilakukan seseorang untuk memperoleh suatu perubahan tingkah laku yang baru secara keseluruhan, sebagai hasil pengalamannya sendiri dalam interaksi dengan lingkungannya.

Menurut pandangan Skinner dalam (Dimyati 9 :2013) bahwa belajar adalah suatu perilaku. Pada saat orang belajar, maka responya menjadi lebih baik. Sebaliknya, bila ia tidak belajar maka responya menurun. Selanjutnya menurut Wilis (2011 :3) belajar dihasilkan dari pengalaman dengan lingkungan, yang di dalamnya terjadi hubungan antara stimulus - stimulus dan respon-respon. 
Prestasi merupakan kecakapan atau hasil kongkrit yang dapat dicapai pada saat atau periode tertentu. Prestasi adalah hasil yang telah dicapai murid dalam proses pembelajaran. Jadi prestasi belajar adalah hasil pengukuran dari penilaian usaha belajar yang dinyatakan dalam bentuksimbol, huruf maupun kalimat yang menceritakan hasil yang sudah dicapai oleh setiap anak pada periode tertentu berikut adalah defenisi prestasi menurut para ahli

Menurut Suryabrata, (2001 :232) Prestasi belajar dapat dikatakan sebagai hasil kecakapan yang baru dari proses belajar seseorang yang mempunyai hasil yang baik dalam belajarnya, berarti ia mendapatkan hasil kecakapan yang baru dari apa yang di pelajarinya.

Sukmadinata (2009:103) "Prestasi belajar atau achievement merupakan realisasi atau pemekaran dari kecakapan-kecakapan potensial atau kapasitas yang dimiliki seseorang. Penguasaan hasil belajar seseorang dapat dilihat dari perilakunya, baik perilaku dalam bentuk penguasaan pengeahuan, ketrampilan berpikir maupun ketrampilan motorik".

Berdasarkan pengertian di atas, maka dapat disimpulkan bahwa belajar adalah suatu proses atau usaha perubahan tingkah laku atau penampilan dalam diri seseorang, dengan serangkaian kegiatan misalnya dengan membaca, mengamati, mendengarkan, meniru dan lain sebagainya. prestasi belajar merupakan tingkat kemanusiaan yang dimiliki murid dalam menerima, menolak dan menilai informasiinformasi yang diperoleh dalam proses belajar mengajar dan Prestasi belajar seseorang sesuai dengan tingkat keberhasilan sesuatu dalam mempelajari materi pelajaran yang dinyatakan dalam bentuk nilai atau raport setiap bidang studi setelah mengalami proses belajar mengajar. Prestasi belajar murid dapat diketahui setelah diadakan evaluasi. Hasil dari evaluasi dapat memperlihatkan tentang tinggi atau rendahnya prestasi belajar murid.

\section{METODE PENELITIAN}

Jenis penelitian yang digunakan adalah penelitian korelasional. Korelasional adalah penelitian yang melihat hubungan antara variabel atau beberapa variabel dengan variabel lain. Desain yang digunakan dalam penelitian ini adalah desain korelasional. Penelitian korelasional menggambarkan suatu pendekatan umum untuk penelitian 
yang berfokus pada penaksiran pada kovariasi di antara dua variable yang muncul secara alami.

Populasi dalam penelitian ini adalah murid SD Negeri Sumanna sebanyak 240 siswa. Sampel pada penelitian ini adalah murid kelas V jumlah sampel yaitu 50 murid. Data yang diperoleh dianalisis dengan megguanakan teknik analisis statitistik deskriptif dan analisis statistik korelasi product moment untuk pengujian hipotesis, yang sebelumnya didahului dengan uji persyaratan analisis uji normalitas data.

\section{HASIL PENELITIAN DAN PEMBAHASAN}

Penelitian yang bertempat di SD Negeri sumanna ini mengambil kelas V sebagai sampel penelitian dengan prosedur pengambilan sampel sistematis. Berdasarkan hasil penelitian yang telah dilakukan, diperoleh data mengenai kedisiplinan belajar murid yang diukur menggunakan angket tertutup. Selanjutnya hasil penelitian ini akan dipaparkan dan dianalisis dengan Statistik Deskriptif dan Korelasi Pearson Product Moment.

\section{Analisi Statistik Deskriptif}

a. Kedisipilinan Belajar

Data yang diperoleh dari hasil angket selanjutnya ditabulasi. Distribusi hasil angket mengenai jawaban responden terhadap setiap item nomor pertanyaan mengenai kedisiplinan belajar dapat dilihat pada tabel distribusi jawaban responden (terlampir). Selanjutnya berikut ini disajikan analisis skor mengenai kedisiplinan belajar sebagai berikut:

Tabel 1 Analisis Distribusi Skor Kedisiplinan Belajar

\begin{tabular}{|l|l|l|l|l|l|l|}
\hline Interval & $\begin{array}{l}\text { Frekuensi } \\
(\boldsymbol{f})\end{array}$ & $\begin{array}{l}\text { Titik tengah } \\
\left.\boldsymbol{X}_{\boldsymbol{i}}\right)\end{array}$ & $\boldsymbol{f} . \boldsymbol{X}_{\boldsymbol{i}}$ & $\boldsymbol{i}-\overline{\boldsymbol{X}}$ & $\left(\boldsymbol{X}_{\boldsymbol{i}}-\overline{\boldsymbol{x}}\right)^{\mathbf{2}}$ & $\boldsymbol{f}\left(\boldsymbol{X}_{\boldsymbol{i}}-\overline{\boldsymbol{x}}\right)^{\mathbf{2}}$ \\
\hline $42-49$ & & 66.5 & 66.5 & & & 12.3904 \\
$50-57$ & & 78.5 & 392.5 & -3.52 & 12.3904 & 359.552 \\
$58-65$ & & 1357. & 8.48 & 71.9104 & 6291.456 \\
$66-73$ & & 102.5 & 5 & 20.48 & 419.4304 & 14769.3056 \\
$74-81$ & & 77,5 & 1435 & 32.48 & 1054.9504 & 839.256 \\
& & & 1162. & 7.48 & 55.9504 & \\
\hline
\end{tabular}


Berdasarkan distribusi di atas maka dapat di hitung skor rata-rata dan standar deviasi sebagai berikut:

$$
\begin{aligned}
& \bar{x}=\frac{\Sigma f \cdot X i}{\Sigma f} \\
& \bar{x}=\frac{3501}{50} \\
& \bar{x}=70.02
\end{aligned}
$$

Berdasarkan analisis tersebut di atas maka hasil skor Kedisiplinan Belajar dapat dideskripsikan pada tabel berikut:

Tabel 2 Deskripsi Skor Kedisiplinan Belajar

\begin{tabular}{|c|c|}
\hline Statistik & Nilai Statistik \\
\hline Ukuran sampel & 50 \\
\hline Skor tertinggi & 81 \\
\hline Skor terendah & 46 \\
\hline Rentang skor & 35 \\
\hline Skor rata-rata & 70.02 \\
\hline
\end{tabular}

Tabel 2 diatas menujukkan bahwa skor rata-rata kedisiplinan belajar murid adalah 70.02. Skor ini terbilang cukup baik dari skor maksimal yang mungkin dicapai yaitu 100. Skor tertinggi kedisiplinan murid adalah 81 skor terendah adalah 46 yang berarti bahwa skor kedisiplinan murid yang menjadi populasi di SD Negeri sumanna tersebar dari skor terendah 46 sampai skor tertinggi 81.

Selanjutnya frekuensi kedisiplinan murid di bagi menjadi lima kategori berdasarkan frekuensi perolehan nilai sebagai berikut:

Table 3 Kategori Kedisiplinan Siswa

\begin{tabular}{|c|l|l|l|c|}
\hline No & $\begin{array}{l}\text { Interval } \\
\text { Skor }\end{array}$ & Frekuensi & Kategori & $\begin{array}{c}\text { Persentase } \\
\%\end{array}$ \\
\hline 1. & $42-49$ & & Sangat Rendah & 2 \\
2. & $50-57$ & & Rendah & 10 \\
3. & $58-65$ & & Sedang & 30 \\
4. & $66-73$ & & Tinggi & 28 \\
\hline
\end{tabular}




\begin{tabular}{|c|c|c|c|c|}
\hline 5. & $74-81$ & & Sangat tinggi & 30 \\
& & & & \\
\hline & & 50 & & $100 \%$ \\
\hline
\end{tabular}

Berdasarkan tabel 4.3 di atas, diketahui bahwa murid dengan kategori kedisiplinan belajar sangat rendah yaitu 1 murid (2\%), murid dengan kategori kedisiplinan rendah ada 5 murid (10\%), kategori sedang dengan frekuensi 15 murid (30\%), kategori tinggi dengan frekuensi 14 murid (28\%), dan kategori kedisiplinan sangat tinggi dengan frekuensi 15 (30\%). Dari hasil analisis di atas dapat disimpulkan bahwa kedisiplinan belajar murid tergolong sedang karena perbandingan banyak murid pada kategori dibawah rata-rata dengan di atas rata-rata, lebih banyak pada kategori kedisiplinan diatas rata-rata.

b. Hasil Belajar

Dari dokumentasi mengenai hasil belajar murid yang berhasil dihimpun, diperoleh distribusi skor/nilai hasil belajar yang menjadi sampel di SD Negeri sumanna sebagai berikut:

Tabel 4 Analisis Distribusi Skor Hasil Belajar

\begin{tabular}{|l|l|l|l|l|l|l|}
\hline Interval & $\begin{array}{l}\text { Frekuensi } \\
(\boldsymbol{f})\end{array}$ & $\begin{array}{l}\text { Titik tengah } \\
\left.\boldsymbol{X}_{\boldsymbol{i}}\right)\end{array}$ & $\boldsymbol{f} . \boldsymbol{X}_{\boldsymbol{i}}$ & $\boldsymbol{X}_{\boldsymbol{i}}-\overline{\boldsymbol{x}}$ & $\left(\boldsymbol{X}_{\boldsymbol{i}}-\overline{\boldsymbol{x}}\right)^{2}$ & $\boldsymbol{f}\left(\boldsymbol{X}_{\boldsymbol{i}}-\overline{\boldsymbol{x}}\right)^{\mathbf{2}}$ \\
\hline $67-71$ & & & 129 & -12.02 & 4.4804 & 288.9608 \\
$72-76$ & & & 592 & -7.02 & 49.2804 & 394.2432 \\
$82-86$ & & & 1185 & -2.02 & 4.0804 & 61.206 \\
$87-91$ & & & 1344 & 2.98 & 8.8804 & 142.0864 \\
\hline Jumlah & & & 801 & 7.98 & 63.6804 & 573.1236 \\
\hline
\end{tabular}

Distribusi skor hasil belajar pada tabel 4 di atas menunjukkan bahwa jumlah frekuensi hasil belajar murid SD Negeri sumanna yang menjadi sampel adalah 50 yang berarti bahwa sampel yang diambil adalah 50 pula. Adapun skor rata-rata hasil belajar murid dan standar deviasinya dapat dihitung dengan acuan hasil analisis di atas sebagai berikut:

$$
\bar{x}=\frac{\Sigma f \cdot X i}{\Sigma f}
$$




$$
\begin{aligned}
& \bar{x}=\frac{4051}{50} \\
& \bar{x}=81,02
\end{aligned}
$$

Berdasarkan analisis tersebut di atas maka skor prestasi belajar dapat dideskripsikan pada table berikut:

Tabel 5 Deskripsi Skor Prestasi Belajar

\begin{tabular}{|c|c|}
\hline Statistik & Nilai Statistik \\
\hline Ukuran sampel & 50 \\
\hline Skor tertinggi & 91 \\
\hline Skor terendah & 70 \\
\hline Rentang skor & 21 \\
\hline Skor rata-rata & 81.02 \\
\hline
\end{tabular}

Tabel 5 di atas menunjukkan skor rata-rata hasil belajar murid SD Negeri sumanna yaitu 81.02. Skor tersebut tergolong tinggi dari skor maksimal yang mungkin dicapai yaitu 91. Adapun jika dikategorikan menurut pedoman pengkategorian Departemen Pendidikan dan Kebudayaan adalah sebagai berikut:

Tabel 6 Kategori Hasil Belajar

\begin{tabular}{|c|c|c|c|c|}
\hline No & Interval & Frekuensi & Persentase (\%) & Kategori Hasil Belajar \\
\hline 1 & $0-34$ & 0 & $0 \%$ & Sangat Rendah \\
2 & $35-54$ & 0 & $0 \%$ & Rendah \\
3 & $55-64$ & 0 & $0 \%$ & Sedang \\
4 & $65-84$ & 34 & $68 \%$ & Tinggi \\
5 & $85-100$ & 16 & $32 \%$ & Sangat tinggi \\
\hline \multicolumn{2}{|c|}{ Jumlah } & 50 & 100 & \\
\hline
\end{tabular}

Table 6 menunjukkan bahwa tidak ada murid yang hasil belajarnya berada pada kategori sangat rendah, rendah, dan sedang (0\%). Selanjutnya 34 murid pada kategori tinggi (68 \%) dan 16 murid pada kategori sangat tinggi (32\%).

Berdasarkan kategori, dapat disimpulkan bahwa hasil belajar murid tergolong tinggi yaitu mencapai $96,30 \%$ dari hasil maksimal yang mungkin dicapai yaitu $100 \%$. Untuk mengetahui besarnya pengaruh kedisiplinan belajar terhadap prestasi belajar murid seperti yang dipaparkan pada hipotesis penelitian maka selanjutnya akan dianalisis menggunakan analisis Korelasi Pearson Product Moment. 


\section{Analisis Korelasi Pearson Product Moment}

Untuk menguji hipotesis dalam penelitian ini digunakan rumus dari Pearson yaitu Korelasi Product Moment. Berikut data hasil penelitian kedisiplinan belajar dengan menggunakan angket dan prestasi belajar murid dari hasil prestasi belajar yang telah dihimpun

Table 4.7 Data Kedisiplinan Belajar (X) dan Hasil Belajar (Y)

\begin{tabular}{|c|c|c|}
\hline Kode Sampel & Disiplin Belajar & Prestasi Belajar \\
\hline 1 & 63 & 75 \\
\hline 2 & 65 & 78 \\
\hline 3 & 73 & 82 \\
\hline 4 & 74 & 83 \\
\hline 5 & 46 & 76 \\
\hline 6 & 78 & 80 \\
\hline 7 & 69 & 70 \\
\hline 8 & 60 & 77 \\
\hline 9 & 74 & 82 \\
\hline 10 & 73 & 82 \\
\hline 11 & 67 & 79 \\
\hline 12 & 75 & 88 \\
\hline 13 & 72 & 86 \\
\hline 14 & 56 & 78 \\
\hline 15 & 70 & 88 \\
\hline 16 & 61 & 87 \\
\hline 17 & 74 & 85 \\
\hline 18 & 57 & 70 \\
\hline 19 & 73 & 88 \\
\hline 20 & 50 & 75 \\
\hline 21 & 70 & 79 \\
\hline 22 & 70 & 81 \\
\hline 23 & 50 & 78 \\
\hline 24 & 65 & 75 \\
\hline
\end{tabular}




\begin{tabular}{|c|c|c|}
\hline 25 & 68 & 78 \\
\hline 26 & 70 & 82 \\
\hline 27 & 80 & 83 \\
\hline 28 & 65 & 76 \\
\hline 29 & 60 & 80 \\
\hline 30 & 63 & 78 \\
\hline 31 & 65 & 85 \\
\hline 32 & 52 & 77 \\
\hline 33 & 70 & 84 \\
\hline 34 & 60 & 75 \\
\hline 35 & 65 & 80 \\
\hline 36 & 76 & 84 \\
\hline 37 & 65 & 80 \\
\hline 38 & 60 & 76 \\
\hline 39 & 73 & 83 \\
\hline 40 & 71 & 82 \\
\hline 41 & 81 & 91 \\
\hline 42 & 64 & 79 \\
\hline 43 & 79 & 89 \\
\hline 44 & 74 & 84 \\
\hline 45 & 78 & 88 \\
\hline 46 & 77 & 87 \\
\hline 47 & 76 & 86 \\
\hline 48 & 61 & 76 \\
\hline 49 & 80 & 90 \\
\hline 50 & 72 & 85 \\
\hline
\end{tabular}

Data tersebut diatas selanjutnya diolah dengan menggunakan rumus Korelasi Pearson Product Moment dengan langkah-langkah sebagai berikut:

a. Memperluas tabel distribusi X dan Y (tabel pembantu untuk menghitung nilai $\mathrm{X}^{2}, \mathrm{Y}^{2}$, dan $\mathrm{XY}$ )

b. Menentukan nilai $r$ dengan rumus korelasi Pearson Product Moment 
c. Membandingkan nilai $r_{\text {hitung }}$ dengan $r_{\text {tabel }}$

Berikut tabel yang memuat nilai $\mathrm{X}$ dan $\mathrm{Y}$ dan tabel-tabel lain untuk memudahkan analisis:

Table 7 Tabel analisis untuk $r$ Product Moment

\begin{tabular}{|c|c|c|c|c|c|}
\hline $\begin{array}{l}\text { Kode } \\
\text { Sampe }\end{array}$ & $X$ & Y & $\mathrm{X}^{2}$ & $\mathrm{Y}^{2}$ & $X Y$ \\
\hline 1 & & 75 & 3969 & 5625 & 4725 \\
\hline 2 & & 78 & 4225 & 6084 & 5070 \\
\hline 3 & & 82 & 5329 & 6724 & 5986 \\
\hline 4 & & 83 & 5476 & 6889 & 6142 \\
\hline 5 & & 76 & 2116 & 5776 & 3496 \\
\hline 6 & & 80 & 6084 & 6400 & 6240 \\
\hline 7 & & 70 & 4761 & 4900 & 4830 \\
\hline 8 & & 77 & 3600 & 5929 & 4620 \\
\hline 9 & & 82 & 5476 & 6724 & 6068 \\
\hline 10 & & 82 & 5329 & 6724 & 5986 \\
\hline 11 & & 79 & 4489 & 6241 & 5293 \\
\hline 12 & & 88 & 5625 & 7744 & 6600 \\
\hline 13 & & 86 & 5184 & 7396 & 6192 \\
\hline 14 & & 78 & 3136 & 6084 & 4368 \\
\hline 15 & & 88 & 4900 & 7744 & 6160 \\
\hline 16 & & 87 & 3721 & 7569 & 5307 \\
\hline 17 & & 85 & 5476 & 7225 & 6290 \\
\hline 18 & & 70 & 3249 & 4900 & 3990 \\
\hline 19 & & 88 & 5329 & 7744 & 6424 \\
\hline 20 & & 75 & 2500 & 5625 & 3750 \\
\hline 21 & & 79 & 4900 & 6241 & 5530 \\
\hline 22 & & 81 & 4900 & 6561 & 5670 \\
\hline 23 & & 78 & 2500 & 6084 & 3900 \\
\hline 24 & & 75 & 4225 & 5625 & 4875 \\
\hline 25 & & 78 & 4624 & 6084 & 5304 \\
\hline 26 & & 82 & 4900 & 6724 & 5740 \\
\hline
\end{tabular}




\begin{tabular}{|c|c|c|c|c|c|}
\hline 27 & & 83 & 6400 & 6889 & 6640 \\
\hline 28 & & 76 & 4225 & 5776 & 4940 \\
\hline 29 & & 80 & 3600 & 6400 & 4800 \\
\hline 30 & & 78 & 3969 & 6084 & 4914 \\
\hline 31 & & 85 & 4225 & 7225 & 5525 \\
\hline 32 & & 77 & 2704 & 5929 & 4004 \\
\hline 33 & & 84 & 4900 & 7056 & 5880 \\
\hline 34 & & 75 & 3600 & 5625 & 4500 \\
\hline 35 & & 80 & 4225 & 6400 & 5200 \\
\hline 36 & & 84 & 5776 & 7056 & 6384 \\
\hline 37 & & 80 & 4225 & 6400 & 5200 \\
\hline 38 & & 76 & 3600 & 5776 & 4560 \\
\hline 39 & & 83 & 5329 & 6889 & 6059 \\
\hline 40 & & 82 & 5041 & 6724 & 5822 \\
\hline 41 & & 91 & 6561 & 8281 & 7371 \\
\hline 42 & & 79 & 4096 & 6241 & 5056 \\
\hline 43 & & 89 & 6241 & 7921 & 7031 \\
\hline 44 & & 84 & 5476 & 7056 & 6216 \\
\hline 45 & & 88 & 6084 & 7744 & 6864 \\
\hline 46 & & 87 & 5929 & 7569 & 6699 \\
\hline 47 & & 86 & 5776 & 7396 & 6536 \\
\hline 48 & & 76 & 3721 & 5776 & 4636 \\
\hline 49 & & 90 & 6400 & 8100 & 7200 \\
\hline 50 & & 85 & 5184 & 7225 & 6120 \\
\hline & $X=3390$ & $\sum Y=4060$ & $\sum X^{2}=233310$ & $\sum Y^{2=}=330904$ & $\sum X Y=276713$ \\
\hline
\end{tabular}

$$
\begin{aligned}
r & =\frac{\mathrm{n} \sum \mathrm{XY}-\left(\sum \mathrm{X}\right)\left(\sum \mathrm{Y}\right)}{\sqrt{\mathrm{n} \sum \mathrm{X}^{2}-\left(\sum \mathrm{X}\right)^{2}} \sqrt{n \sum \mathrm{Y}^{2}-\left(\sum \mathrm{Y}\right)^{2}}} \\
& =\frac{50 \mathrm{X} 276713-(3390)(4060)}{\sqrt{50 \mathrm{X}} 233310-11492100 \sqrt{50 \mathrm{X} 330904-16483600}} \\
& =\frac{13835650-13763400}{\sqrt{(173400)(61600)}}
\end{aligned}
$$




$$
\begin{aligned}
& =\frac{72250}{\sqrt{10681440000}} \\
& =\frac{72250}{103351,1} \\
r x y & =0,69 \\
(r)^{2} & =0.69^{2} \\
& =0,47 \\
\text { Hasil } & 0.69^{2}=0,47 \times 100 \\
& =47 \% \stackrel{ }{\longrightarrow} 53 \% \text { (pengaruh prestasi belajar) }
\end{aligned}
$$

Jadi $47 \%$ jumlah disiplin sedangkan prestasi belajar adalah $53 \%$.

Berdasarkan hasil olah data di atas, maka diperoleh $r_{\text {hitung }}$ sebesar 0,69 Untuk mengetahui apakah kedisiplinan berpengaruh terhadap prestasi belajar,

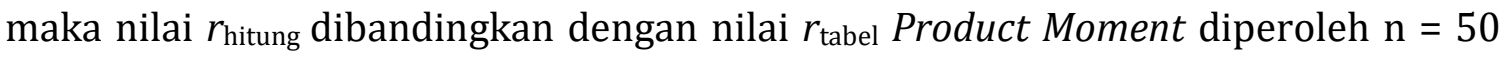
maka nilai $r_{\text {tabel }}$ yaitu 0,279. Hasil olah data menunjukkan nilai $r_{\text {hitung }}>r_{\text {tabel }}$ ini berarti terdapat pengaruh kedisiplinan belajar terhadap hasil belajar murid yang menjadi populasi. Berpatokan pada tabel interpretasi koefisien korelasi nilai $r$, pengaruh kedisiplinan belajar terhadap hasil belajar pada populasi tergolong tinggi.

Tabel 8 Koefisien Korelasi

\begin{tabular}{|l|l|}
\hline Interval Koefisien & Tingkat Hubungan \\
\hline $0,00-0,199$ & Pengaruh variabel Sangat rendah \\
\hline $0,20-0,399$ & Pengaruh variabel Rendah \\
\hline $0,40-0,599$ & Pengaruh variabel Cukup \\
\hline $0,60-0,799$ & Pengaruh variabel Tinggi \\
\hline $0,80-1,000$ & Pengaruh variabel Sangat Tinggi \\
\hline
\end{tabular}

\section{SIMPULAN DAN SARAN}

Kesimpulan dalam penelitian ini adalah bahwa terdapat pengaruh kedisiplinan belajar terhadap prestasi belajar murid kelas V SD Negeri sumanna. Hal ini sesuai dengan hasil penelitian sebagai berikut: (1) Setelah data hasil angket diolah, diperoleh nilai rata-rata kedisiplinan siswa sebesar 70.02 Skor ini tergolong cukup tinggi dari skor ideal yang mungkin dicapai yaitu 100. Hasil olah data dokumentasi hasil belajar siswa menunjukkan rata-rata hasil belajar siswa sebesar 81.02. Hasil ini tergolong tinggi berdasarkan pedoman kategorisasi Departemen Pendidikan dan Kebudayaan karena frekuensi hasil belajar siswa paling banyak pada interval 65 - 84 sekitar $96 \%$ dari 
keseluruhan total skor yang mungkin dicapai. (2) Hasil analisis data dengan Korelasi Pearson Product Moment menunjukkan bahwa nilai $r_{\text {hitung }}$ sebesar 0,69 dan nilai $r_{\text {tabel }}$ Product Moment untuk n = 50 yaitu 0,279. Hal ini berarti nilai $r_{\text {hitung }}>r_{\text {tabel }}$ sehingga dinyatakan terdapat pengaruh kedisiplinan belajar terhadap prestasi belajar murid di SD Negeri sumanna

Kedisiplinan belajar murid masih perlu untuk ditingkatkan. Berbagai hal yang menyangkut kedisiplinan dari berbagai macam faktor yang mungkin mempengaruhi kedisiplinan tidak meningkat masih perlu untuk dibenahi. Melihat hasil dari penelitian ini bahwa kedisplinan itu sendiri mempunyai pengaruh yang positif terhadap peningkatan hasil belajar murid, maka diharapkan antara guru dan orangtua mampu bekerja sama agar kedepannya kedisiplianan belajar murid semakin meningkat sehingga diharapkan hasil belajarnya juga ikut meningkat.

\section{DAFTAR PUSTAKA}

Arif Gunarso.1993. Bagaimana Bimbingan dan Penyuluhan Belajar di Sekolah, Surabaya : Usaha Nasional.

Arikunto, Suharsimi. 2005. Prosedur Penelitian suatu Pendekatan Praktek. Jakarta Rineka Cipta.

Dimyati, (2013). Belajar dan pembelajaran. Jakarta :PT RinekaCipta.

Hurlock, Elizabeth. (1999). Psikologi Perkembangan (suatu pendidikan sepanjang rentang kehidupan). Jakarta :Gelora Aksara Pratama

Koesoema, Doni. 2011. Pendidikan Karakter Strategi Mendidik Anak di Zaman Global. Jakarta: Grasindo

Meichati, Siti.1993. Psikologi Pendidikan (Terjemahan). FIP - IKIP Yogyakarta.

Ma'sumah, Siti. (2015). Hubungan Disiplin Belajar Terhadap Prestasi Belajar Siswa Kelas IV Sekolah Dasar Negeri Se-Daerah Binaan II Kecamatan Pertahanan Kabupaten kebumen.Skripsi Publikasi.Semarang: Universitas Negeri Semarang

Mulyasa, E. (2003). Kurikulum Berbasis Kompetensi. Bandung :Remaja Rosda karya

Njoroge, Philomena Mukami and Ann Nduku Nyabuto. 2014. Discipline as a Factor in Academic Performance in Kenya. Journal of Educational and Social Research. (Online). Vol.4 No.1. Tersedia: http://www.mcser.org/journal/index.php/jesr/article/view/1847. Diunduh 9 Januari 2015.

Nursisto. (2008). Mengenal Pelanggaran Tata Tertib di Sekolah tarmizi. Wordpress. Com. (online). 
Poerwodarminto, W.J.S. 1997. Kamus Umum Bahasa Indonesia. Jakarta : Balai Pustaka.

Purwanto, Ngalim. 2014. Ilmu Pendidikan Teoretis dan Praktis. Bandung:

Remaja Rosdakarya

Ruswandi. (2013). Psikologi Pembelajaran. Bandung: Cipta Pesona Sejahtera

Slameto. (2003). Belajar dan Faktor-faktor yang Mempengaruhinya. Jakarta: Rineka Cipta

Soewondo. (1982). Kamus Besar Bahasa Indonesia. Jakarta: Balai Pustaka

Suryabrata, Sumadi. (2001). Metodologi Penilitan. Jakarta: Raja Grafindo Persada

Sugiyono. (2013). Metode Penelitian Pendidikan Pendekatan Kuantitatif.. Bandung :Alfabeta

Tu"u, Tulus. 2004. Peran Disiplin pada Perilaku dan Prestasi Siswa. Jakarta: Grasindo.

Wilis Dahar Ratna. (2011). Teori-teori Belajar \& Pembelajaran. Bandung: Penerbit Erlangga.

Wibisono, Jarwot. (2010). Hubungan Disiplin Belajar Terhadap Prestasi Belajar Pendidikan Agama Islam Siswa SD Negeri Ngajaran 03 Kecamatan Tuntang Kabupaten Semarang Tahun Pelajaran 2009/2010 Salatiga: Sekolah Tinga.

WS. Winkel (1996) . Psikologi Pendidikan dan Evaluasi Belajar. Jakarta: PT Gramedia.

Zuriah, Nurul. 2007. Metodologi Penelitian Sosial dan Pendidikan. Jakarta: Bumi Aksara.cp 